Bangladesh J. Bot. 48(4): 1125-1132, 2019 (December)

\title{
COMPARATIVE ANALYSIS OF BIO-CULTURING OF FRESH WATER ALGAE, SPIROGYRA COMMUNIS (HASSALL) KÜTZING AND HYDRODICTYON RETICULATUM L.
}

\author{
Mehwish Jaffer*, Hammad Ashraf ${ }^{1}$ and Shabnum Shaheen \\ Department of Plant Taxonomy, Lahore College for Women University, \\ Lahore, Pakistan
}

Keywords: Comparative analysis, Bio-culturing, Freshwater algae

\begin{abstract}
For optimization of cultural conditions for algal biomass production of two local filamentous freshwater algae, namely Hydrodictyon reticulatum, and Spirogyra communis were cultured. Among all these tested media, $H$. reticulattum gave maximum biomass $(18.6 \mathrm{~g} / \mathrm{l})$ in Bristol medium whereas, $S$. communis gave the biomass of $10.5 \mathrm{~g} / \mathrm{l}$ in Bristol soil media. Then the effect of different carbon sources (lactose, glucose, cellulose and starch) supplement in Bristol media was evaluated for biomass production. Among all the sources cellulose at $1 \mathrm{~g} / \mathrm{l}$ was found to be significant for optimal mass production of $(15.81 \mathrm{~g} / \mathrm{l})$ and $(18.6 \mathrm{~g} / \mathrm{l})$ of $S$. communis and $H$. reticulatum, respectively. Both the algal species gave insignificant results in all other carbon sources. The effect of different nitrogen sources (ammonium nitrate, ammonium sulphate, ammonium chloride, potassium nitrate and urea) was tested for biomass production. Urea at $0.1 \mathrm{~g} / \mathrm{l}$ was found to be best $(20.7 \mathrm{~g} / 1000 \mathrm{ml})$ for optimal growth of $\mathrm{H}$. reticulatum as compared to $(16.86 \mathrm{~g} / 1000 \mathrm{ml})$ of S. communis. However, cellulose as carbon source and urea as nitrogen source were optimized for significant growth of both the algal species. The comparison between the growth rates of both specimens was evaluated. Both the species gave maximum growth up to 15 days of incubation and then the growth started decreasing gradually. It is indicated that the volumetric growth of $H$. reticulatum is significant in the selected media as compared to S. communis.
\end{abstract}

\section{Introduction}

The production of algal biomass has been a worth praising achievement in the field of industrial microbiology. The algae commenced several commercial applications in the field of nutrition, medicine, pharmaceutical, cosmetics, waste removal, biofuel and as fertilizer. But algae still remain neglected although they contain all the important constituent that proved to be worth praising for future development and enhanced economy of country. It is worthwhile to isolate, and optimize the culture conditions for algal biomass production (Beardall and Ravan 2004, Barsanti and Gualtieri 2006, Schenk et al. 2008, Khola and Gazala 2012). For culturing the algal biomass various biotic and abiotic factors are involved with the in vitro mass production of algae. Number of culturing strategies has been advanced through which high yield algal cultures may be executed (Huber and Dale 2009).

Essentially, an excessive yield culture entirely depends upon a good nutrition source. Adequate supply of nutrients in culture media might enable to flourish the algal culture (Munir et al. 2015). Carbon, nitrogen, phosphorous and sulphur are important elements constituting algal cells. Other essential trace elements include iron, magnesium and sulphur (Bala 2006, Cao et al. 2016). These, elements are important to develop balanced media for optimal micro-algal cultivation and carbon and nitrogen are the most important nutrients, which contribute to the biomass production (Zulkifly 2013).

*Author for correspondence: <meh.jaffer@gmail.com>. ${ }^{1}$ Plant Phycology Laboratory, Government College of Science, Wahdat Road, Lahore, Pakistan. 
Mixed effect of nitrogen and carbon complements the algal increase but as the concentration increases the impact on biomass production decreases. Because high degree of nitrogen hindered the mobile, growth and can cause the breathing, which might also be enhancer for biomass manufacturing (Ogbonna et al. 2000, Kim et al. 2002).

However, the present study is concerned with the collection and isolation of filamentous green and optimization of cultural condition such as selection of growth media, effect of carbon and nitrogen sources on the mass production of selected filamentous algae.

\section{Materials and Methods}

The research work was conducted during 2016 - 2017 in Research laboratory, Department of Botany, Government. College of Science, Lahore. The study was confined for the optimization of different cultural conditions for the production of algal biomass. Different algal specimens were collected in a plastic bottle from different areas of Lahore. The samples were then washed properly with tap water using $0.25 \mu \mathrm{m}$ pore size sieve. The collected species were then taxonomically identified according to Prescott (2007). Among all the identified specimens these two specimens were selected for further experimental analysis. The identified samples as shown in Fig. 1 were then cultured on different media.
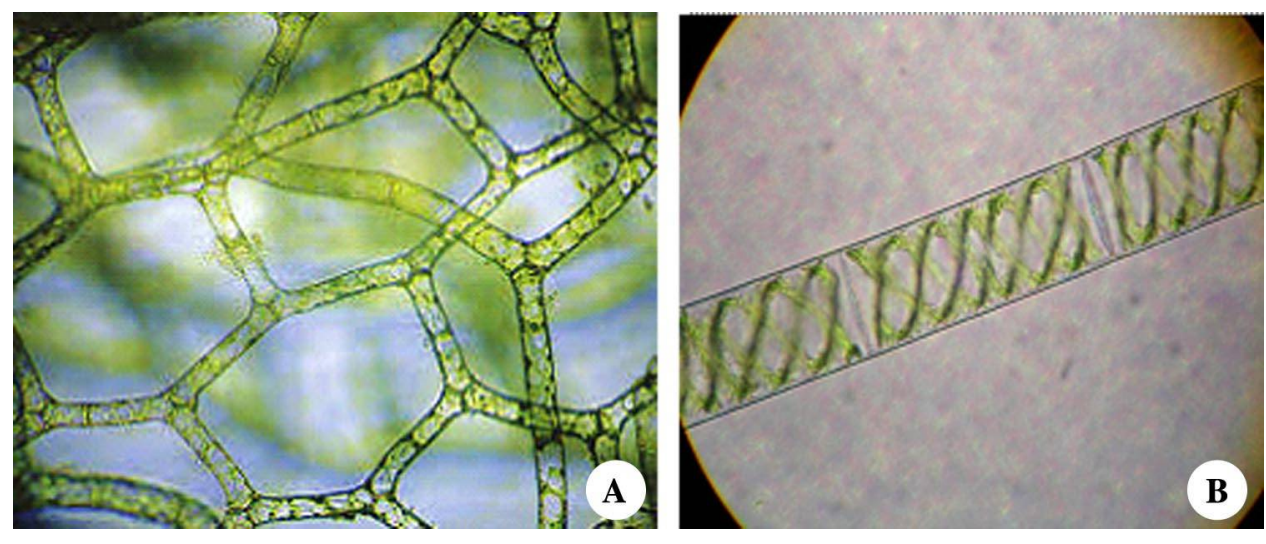

Fig. 1. Selected algal species for biomass production. A. Hydrodictyon reticulatum, B. Spirogyra communis.

\begin{tabular}{llll}
\hline S1. No. & Species & Family & Locality \\
\hline 1 & Hydrodictyon reticulatum L. & Hydrodictyaceae & Head Baloki \\
2 & $\begin{array}{l}\text { Spirogyra communis (Hassall) } \\
\text { Kützing }\end{array}$ & Zygnemataceae & Ravi siphon \\
& & \\
\hline
\end{tabular}

For culturing these specimens, different culture media viz. A - Z media (Prescott 2007) M1, Bristol's media (Alam et al. 2015) M2 and Bristol's soil media (Bristol media along with $10 \mathrm{~g}$ soil) M3 were used for the biomass production. For culturing the algae in laboratory different media were used for their bulk biomass production. The media used were M1, M2 and M3 media and the experiment was carried out in $1000 \mathrm{ml}$ glass beaker containing 1 litre of one of the abovementioned media. The media were prepared by following the standard protocol. After that $3 \mathrm{~g}$ of algae was added in the media and $\mathrm{pH}$ of the media was adjusted up to 8.00 . The beakers were then 
exposed to sunlight for $6 \mathrm{hrs}$ every day for optimum growth of algal species. The same protocol was followed for all the respective media and each experiment was run in triplicate.

The biomass productivity $\mathrm{P}$ (mg/l/day) was calculated by following equation:

$$
\mathrm{P}=\frac{\mathrm{W}_{2}-\mathrm{W}_{1}}{\mathrm{t}}
$$

where, $\mathrm{W}_{1}$ is the initial biomass concentration, $\mathrm{W}_{2}$ is the biomass concentration at the last day of cultivation, $t$ is the cultivation time.

Effect of different carbon sources (sucrose, glucose, cellulose, maltose and lactose) and their concentrations $(0.4-3.0 \%)$ on algal growth was also tested with selected Bristol growth media (Prabakaran and Raavindran 2012). Same as the effect of different nitrogen sources (ammonium sulphate, ammonium nitrate, potassium nitrate, urea and ammonium chloride) and their various concentrations $(0.1-1.0 \%)$ on algal growth were studied using the selected Bristol growth medium (Nigam et al. 2011). The experiment was performed for 20 days. At initial $\mathrm{pH}$ of medium was adjusted to 8.0.

The data were further analysed by ANOVA with three-way complete randomized designs (Steel and Torrie 1984) to know significant differences between various means and also within the blocks of treatments and the types of microorganisms.

\section{Results and Discussion}

The work was done to study the biomass production, effect of different nutritional sources, and cultural media on algal growth. While culturing algae the main purpose was to select the cheapest methods and easily available sources and also culturing was conducted by keeping in mind the commercial and economical perspective.

As the constituents of the media were different, their effects on biomass were also different. Fig. 2 indicates the effect of different cultured media on algal biomass growth. Three cultured media M1, M2, M3 were used for algal biomass production. Among all the media Bristol's soil medium M3 gave $18.6 \mathrm{~g} / \mathrm{l}$ and $10.5 \mathrm{~g} / \mathrm{l}$ as maximum growth for both $H$. reticulatum and $S$. communis whereas Bristol's medium gave $10.6 \mathrm{~g} / \mathrm{l}$ and $8.4 \mathrm{~g} / \mathrm{l}$ as intermediate growth for both algae. These results showed that the Bristol's soil medium was best suitable medium for maximum yield of both $H$. reticulatum and $S$. communis. As the chemical constituent of these medium contain both the macro and micro elements which were mainly necessary for the algae to grow and the soil used gave the proper habitat to algae, so the sample grew preferably in it. So, this medium was selected for the further studies.

Carbon acts as main growth factor that directly or indirectly effects the algal growth. Fig. 3 indicated the effect of different carbon sources on algal biomass growth. Four different carbon sources (sucrose, glucose, cellulose, maltose and lactose) were used for algal mass culturing. Among all the carbon sources cellulose proved to be best and showed increase in biomass up to10.7 $\mathrm{g} / \mathrm{l}$ of $\mathrm{H}$. reticulatum and $10.3 \mathrm{~g} / \mathrm{l}$ of $S$. communis within 20 days. While glucose from the other sources gave $9.4 \mathrm{~g} / \mathrm{l}$ of $\mathrm{H}$. reticulatum and $7.5 \mathrm{~g} / \mathrm{l}$ of $S$. communis, lactose gave $8.3 \mathrm{~g} / \mathrm{l} \mathrm{of} \mathrm{H}$. reticulatum and $6.9 \mathrm{~g} / \mathrm{l}$ of Spirogyra and maltose gave $8.1 \mathrm{~g} / \mathrm{l}$ of $H$. reticulatum and $7.4 \mathrm{~g} / \mathrm{l}$ of S.communis. These outcomes indicated that each species has different carbon source requirement for its proper growth as nourishment (Negoro et al. 1991, Zarina et al. 2009). The research explores that there may be present a cellulose degrading bacteria that firstly degrade the cellulose to cellobiose and then into glucose subunits that may directly influence the algal biomass to grow. 
In this way the carbon source was available in two different forma at two different stages. So this source was selected for further studies.

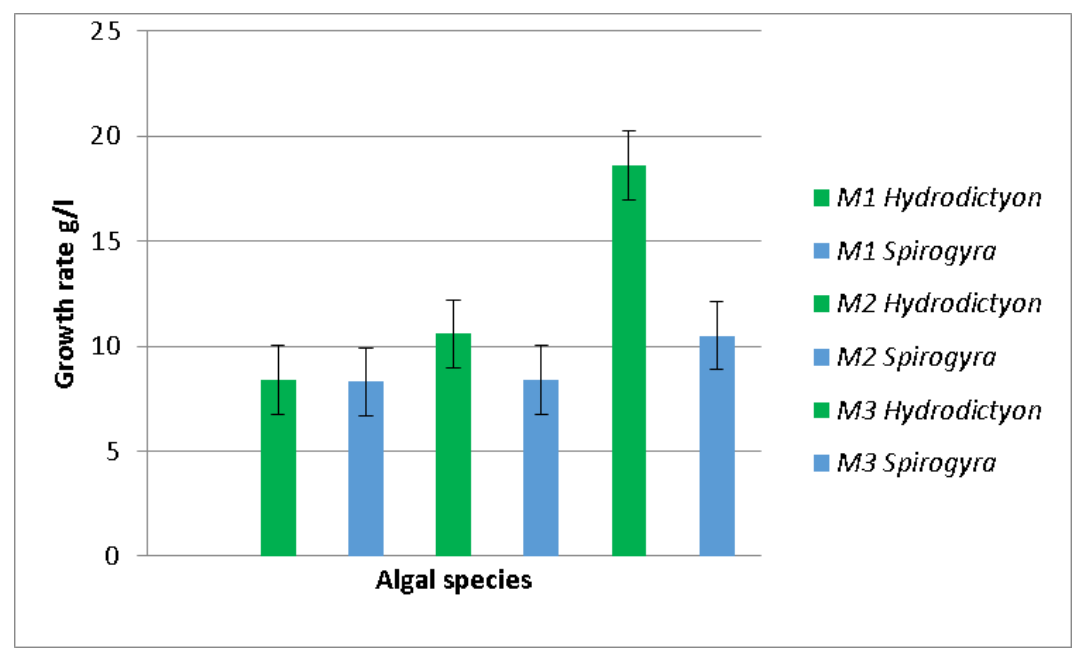

Fig. 2. Influence of diverse culture media on algal biomass production (DMRT, $\mathrm{p}<0.05$ ).

Bars indicate \pm S.E. $(n=3)$

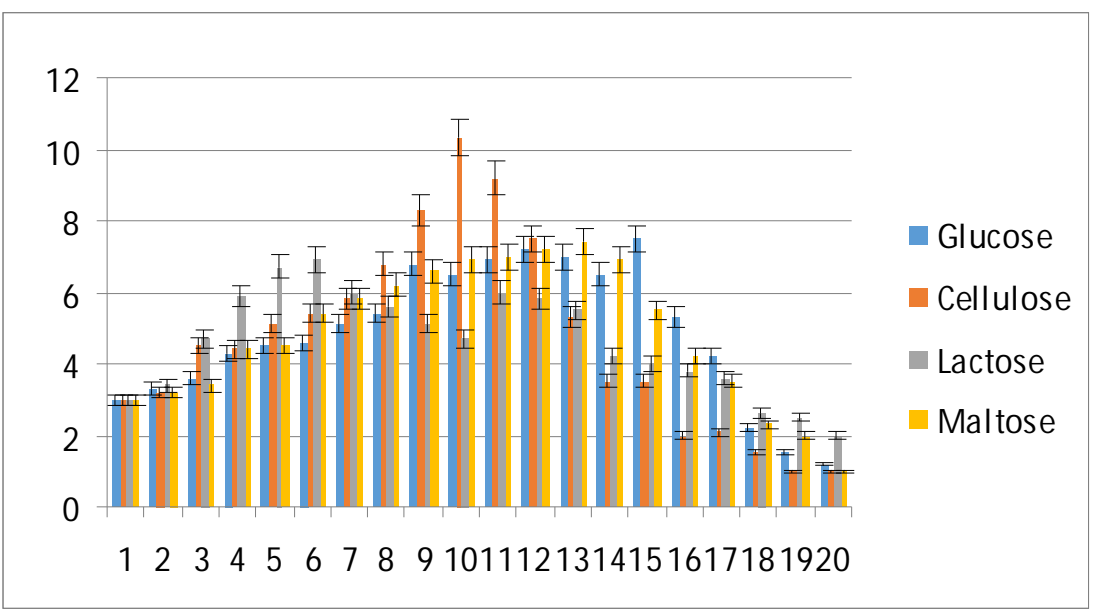

Fig. 3. Influence of diverse carbon sources on $H$. reticulatum biomass production (DMRT, $\mathrm{p}<0.05)$. Bars indicate \pm S.E. $(\mathrm{n}=3)$.

The selected cellulose was then employed to check that at what concentration it may be beneficial for algae to increase its biomass. The Fig. 4 indicated the effect of variable concentration of cellulose on algal biomass. Four different concentrations of cellulose 0.5, 1, 1.5 and $2 \mathrm{~g}$ were used on algal growth. The results specified that the $1 \mathrm{~g}$ cellulose gave the best algal biomass $18.7 \mathrm{~g} / \mathrm{l}$ of $H$. reticulatum and $15.81 \mathrm{~g} / \mathrm{l}$ of $S$. communis whereas $1.5 \mathrm{~g}$ cellulose gave the algal mass $8.1 \mathrm{~g} / \mathrm{l}$ of $H$. reticulatum and $8.9 \mathrm{~g} / \mathrm{l}$ of $S$. communis, on the contrary use of $2 \mathrm{~g}$ gave the algal mass of $11.5 \mathrm{~g} / \mathrm{l}$ of $H$. reticulatum and $8.7 \mathrm{~g} / \mathrm{l}$ of $S$. communis. These results suggested that 1 
$\mathrm{g}$ cellulose in $1000 \mathrm{ml}$ of cultured medium is best for algal biomass production. Because cellulose was easily available and consumed by algae as compared to the other sources applied and the respective algae require cellulose as its carbon source (Lee and Poulickova 2004).

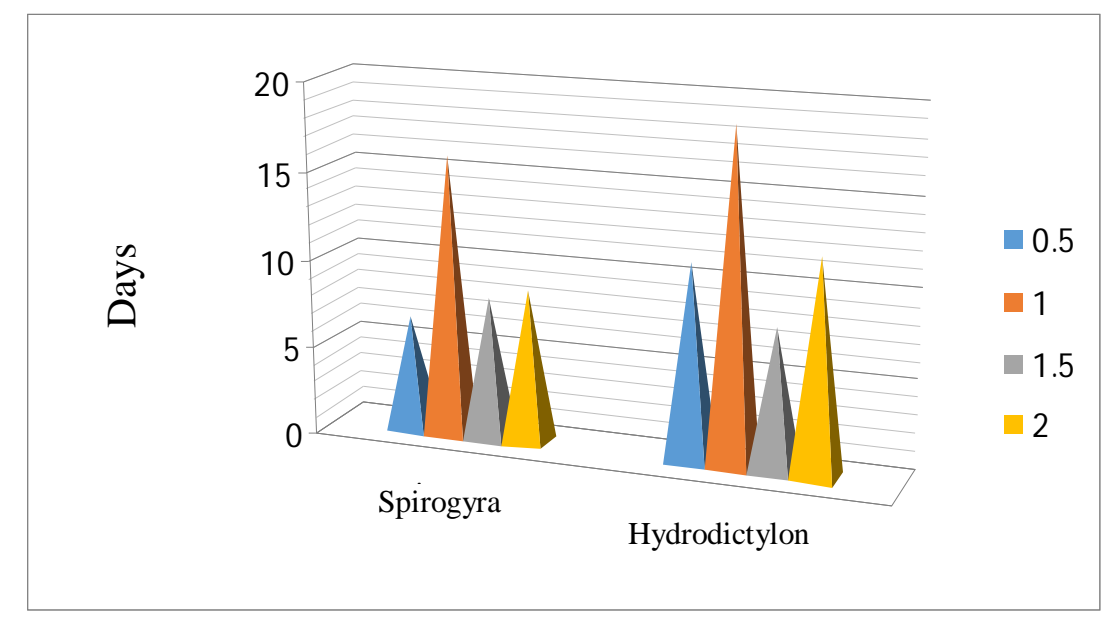

Fig. 4. Effect of different concentrations of cellulose on algal growth.

The Fig. 5 specified the effects of different nitrogen sources on algal biomass production. Four different nitrogen sources (ammonium sulphate, ammonium nitrate, potassium nitrate, urea and ammonium chloride) were used for this purpose. The data from results showed that among all nitrogen sources urea gave the best results of $12.5 \mathrm{~g} / \mathrm{l}$ of $\mathrm{H}$. reticulatum and $8.6 \mathrm{~g} / \mathrm{l}$ of $S$. communis. Whereas ammonium sulphate gave $4.3 \mathrm{~g} / \mathrm{l}$ of $H$. reticulatum and $3.9 \mathrm{~g} / \mathrm{l}$ of $S$. communis and ammonium chloride similarly gave $8.0 \mathrm{~g} / \mathrm{l}$ of $H$. reticulatum and $4.6 \mathrm{~g} / \mathrm{l}$ of $S$. communis. Potassium nitrate and ammonium nitrate gave $4.3,3.0 \mathrm{~g} / \mathrm{l}$ of $H$. reticulatum and $3.8,3.7 \mathrm{~g} / \mathrm{l}$ of $S$. communis. Thus, there is a high probability of loss of ammonia due to the high $\mathrm{pH}$ around $8.5-9.5$. That's why urea proves to be the best nitrogen source for algae to increase its biomass. Therefore, it seems that the nitrogen consumption by algal cells was the largest in medium with urea and not ammonium, as the cell growth rate supports this. These data showed that urea is the best suited for algal mass production, and it was further tested by Yoshihara et al. (1996).

The selected urea was then utilized to study that at what focus it might be advantageous for algae to increase its biomass. The Fig. 6 shows that by using variable concentrations of urea only $10 \mathrm{mg}$ urea was best suited for biomass production of $20.7 \mathrm{~g} / \mathrm{l}$ of $\mathrm{H}$. reticulatum and $16.86 \mathrm{~g} / \mathrm{l}$ of $S$. communis. While $20 \mathrm{mg}$ gave the algal mass of $6.5 \mathrm{~g} / \mathrm{l} \mathrm{of} \mathrm{H}$. reticulatum and $5.3 \mathrm{~g} / \mathrm{l}$ of $S$. communis while $30 \mathrm{mg}$ gave the algal mass of $8.9 \mathrm{~g} / \mathrm{l}$ of $\mathrm{H}$. reticulatum and $4.4 \mathrm{~g} / \mathrm{l}$ of $S$. communis and $40 \mathrm{mg}$ gave the algal mass of $4.3 \mathrm{~g} / \mathrm{l}$ of $H$. reticulatum and $3.9 \mathrm{~g} / \mathrm{l}$ of $S$. communis. Results indicated that only $10 \mathrm{mg}$ concentration of urea gave the maximum growth as nitrogen in urea form was the available source for algae and algal biomass consume easily nitrogen in urea form. Same result was observed by Cheirsilp and Torpee (2012). The $20 \mathrm{mg}$, urea gave the best algal biomass as nitrogen in form of urea and which found to be the best nitrogen source for algal growth (Yang et al. 2000, Teoh et al. 2013). 


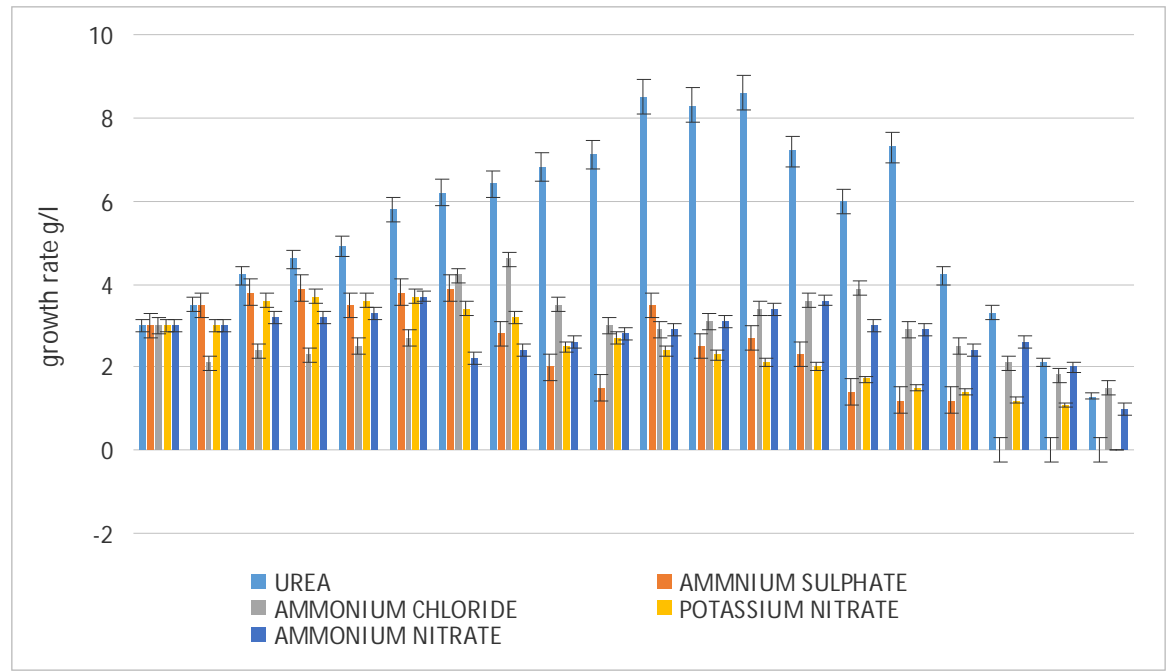

Fig. 5. Effect of different nitrogen sources on $S$. communis biomass production (DMRT, $\mathrm{p}<0.05)$. Bars indicate \pm S.E. $(\mathrm{n}=3)$.

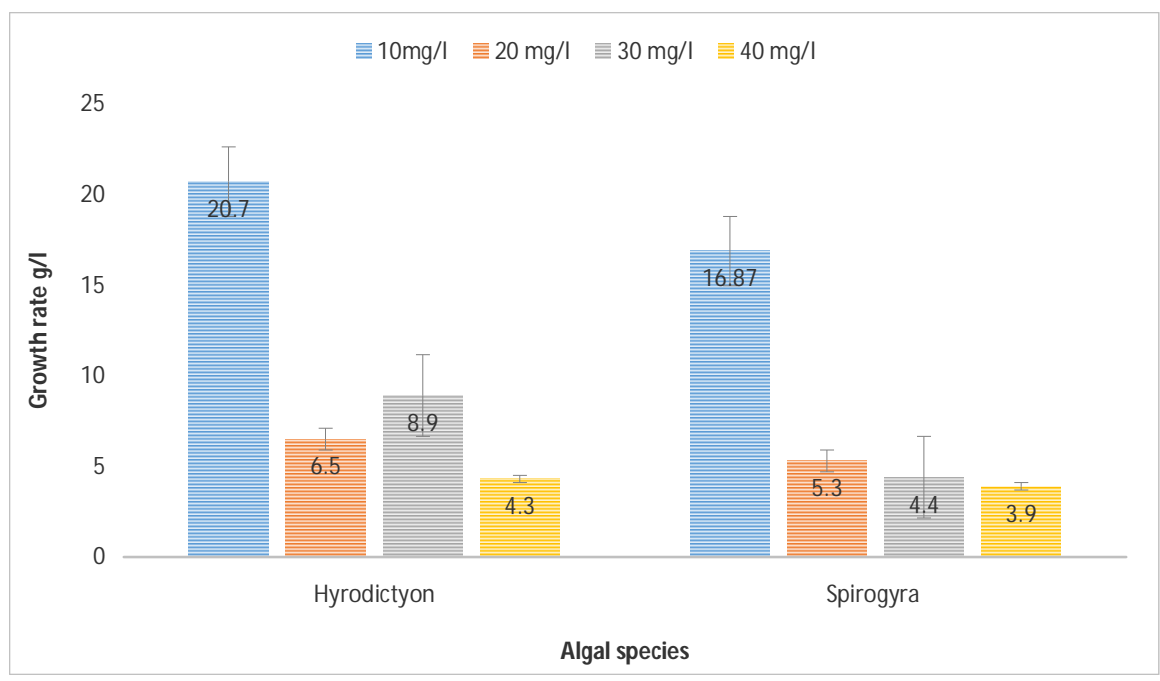

Fig. 6. Effect of different concentrations of urea on biomass production of algae (DMRT, $\mathrm{p}<0.05)$. Bars indicate \pm S.E. $(\mathrm{n}=3)$.

To study the growth rate and mass production of $H$. reticulatum and $S$. communis, these specimens were cultured for 20 days in the Bristol soil media using the cellulose as carbon and urea as a nitrogen source at $\mathrm{pH} 8$ and the temperature was maintained up to $25 \pm 2^{\circ} \mathrm{C}$ (Fig. 7). Results showed that algal growth increased day by day till the 15 days, afterwards there was minor increase, or it was stationary and after 18 days the decline rate started. It was observed that $H$. reticulatum achieved its maximum growth in approximately 15 days. 


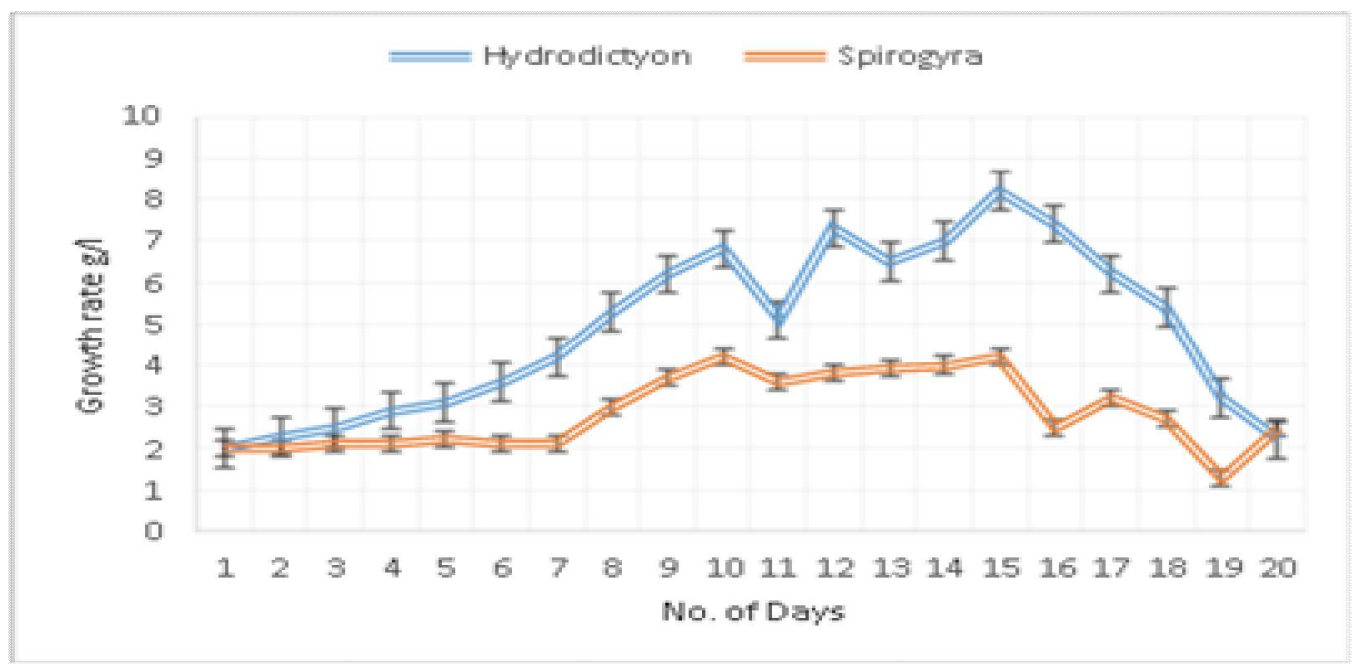

Fig. 7. Comparison between the growth rates of algal biomass

(DMRT, $\mathrm{p}<0.05)$. Bars indicate \pm S.E. $(\mathrm{n}=3)$.

Keeping in mind the increasing demand of algae as an alternative to food, medicine, color and dietary supplement, it is necessary to harvest algae in bulk mass. As algae is temperature dependent, a minor fluctuation in temperature results in spoilage of algae. So, it is necessary to culture algae in laboratory and increase its biomass. For biomass production specific growth media containing the major carbon and nitrogen source were used, so that at any time and at any season algae will be obtained easily.

\section{Acknowledgements}

This work was conducted as a Ph.D. research work in Department of Botany, Government College of Science, Lahore. Thanks to the authority of the Department for providing facilities for conducting the work.

\section{References}

Alam A, Saleem U, Alam S, Shah HU, Aftab S, Siddiq M and Manzoor N 2015. Influence of culture media and carbon sources on biomass productivity and oil content of the algae Sirogonium sticticum, Temnogyra reflexa, Uronema elonggaatum, and Chroococcus turgidus. Turk. J. Bot. 39: 1405-1416.

Bala, B K 2006. Studies on biodiesel from transformation of vegetable oils for diesel engines. Energy Educ Sci. Technol. 15: 1-45.

Barsanti, L and Gualtieri, P 2006. Algae biotechnology. In: Algae: Anatomy,Biochemistry, and Biotechnology CRC Press Taylor and Francis Group, Boca Raton. pp. 324-359.

Beardall J and Raven JA 2004. The potential effects of global climate change on microalgal photosynthesis, growth and ecology. Phycologia 43: 26-40

Cao X, Zhou Y, Wang Z and Song C 2016. The contribution of attached bacteria to bloom: Evidence from field investigation and microcosm experiment. Geomicrobiol. J. 33: 607-617

Cheirsilp B and Torpee S 2012. Enhanced growth and lipid production of microalgae under mixotrophic culture condition: Effect of light intensity, glucose concentration and fed-batch cultivation. Bioresour. Technol. 110: 510-516. 
Huber GW and Dale B E 2009. Biofuels: Grassoline at the Pump. Sci. American 301(1): 52.-59.

Khola G and Ghazala B 2012. Biodiesel production from algae. Pak. J. Bot. 44(1): 379-381.

Kim JN, Suh IS, Hur BK and Lee CG 2002. Simple mono dimensional model for linear growth rate of photosynthetic microorganisms in flat-plate photobioreactors. J. Microbiol. Biotechnol. 12(6): 962-971.

Lee E and Poulickova A 2004. The influence of Hydrodictyon reticulatum (L.) on diurnal changes in environmental variables in a shallow pool. Czech. Phycol. 4(103): 103-109.

Munir N, Imtiaz A, Sharif N and Naz Z 2015. Optimization of growth conditions of different algal strains and determination of their lipid content. J. Ani. Plant Sci. 25(2): 546-553.

Negoro M, Shioji M and Miura Y 1991. Growth of micro algae in high $\mathrm{CO}_{2}$ gas and effects of Sox and Nox. J. App. Biochem. Biotechnol. 28(29): 877-886.

Ogbonna JC, Yoshizawa H and Tanaka H 2000. Treatment of high strength organic wastewater by a mixed culture of photosynthetic microorganisms. J. Appl. Phycol. 12: 277-284.

Prabakaran P and Ravindran D A 2012. Scenedesmus as a potential source of biodiesel among selected microalgae. Curr. Sci. 102: 616-619.

Prescott GW 2007. Algae of the western great lakes area. 9th ed. John Wiley and Sons. New York.

Rai U, Deshari G, Rai B, Bhattarain K, Dhakal RP and Rai SK 2013. Isolation and culture condition optimization of Chlorella vulgaris. Nep. J. Sci. Technol. 4(2): 43-48.

Schenk PM, Thomas-Hall SR, Stephens E, Marx UC, Mussgnug JH, Posten C, Kruse O and Hankamer B. 2008. Second generation biofuels: High-efficiency microalgae for biodiesel production. Bioenerg. Res. 1: 20-43.

Snedecor GW and Cochrane WG 1980. Statistical methods. 7th ed. Ames, Iowa: Iwoa State University Press. ISBN 0-81381560-6.

Steel RGD and Torrie JH 1960. Principles and Procedures of Statistics. McGraw-Hill, New York.

Teoh ML, Phang SM and Chu WL 2013. Response of Antarctic, temperate, and tropical microalgae to temperature stress. J. Appl. Phyco. 125: 285-297.

Yang C, Hua Q and Shimizu K 2000. Energetics and carbon metabolism during growth of microalgal cells under photoautotrophic, mixotrophic and cyclic light-autotrophic/dark-heterotrophic conditions. Biochem. Eng. J. 6: 87-102.

Yoshihara K, Nagase H, Eguchi K and Miyamoto K 1996. Biological elimination of nitiric oxide and carbon dioxide from flue gas by marine microalgae $\mathrm{NO}_{4}-113$ cultivated I long tubular photobioreactor. J. Ferment. Bioeng. 82: 351-354.

Zarina A, Hasan MU and Shameel M 2009. Diversity of freshwater green macroalgae in the Punjab and neighboring areas of Pakistan. Pak. J. Bot. 41(1): 277-291.

Zulkifly SB, Graham JM, Young EB, Mayer RJ, Piotrowski MJ, Smith I and Graham LE 2013. The genus ecological engineer. J. Phyco. 149: 1-17. 